\title{
Treasury Single Account - Transparency and Accountability in Public Finance Management in Nigeria: The Journey So Far
}

IGBOKWE-IBETO, C. J. | NKOMAH, B. B. || OSAKEDE, K. 0. | KINGE, R. F.

Abstract

he purpose of this article is to
evaluate and critique the policy of Treasury Single Account (TSA) adopted by the Nigerian government as an essential tool for enhancing transparency and accountability in public sector financial. Theoretically, it is expected that TSA would bring about mutual benefit, halt economic injustice and engender financial discipline, transparency, accountability, a new economic and political order in Nigeria. However, in the public sector management and political economy of Nigeria, its impact has been a mixed bag of the good, the bad and the ugly. Within the framework of New Public Management approach, the paper explores the gamut of issues surrounding the implementation of TSA and concludes that, for an administration that has social contract with Nigerians in terms of service delivery; it has the obligation to aggregating states' resources to provide social services, amenities and infrastructural development to the people. Any step taking to ensure accountability and transparency by revenue generating agencies of government should be seen as a step in the right direction. However, while change is desirable, we feel there is need to exercise caution on account of the peculiar nature and character of the Nigerian state and society. Given the catalogue of challenges facing the operations TSA, it recommends among others, that the adoption of TSA in the country's public sector should progress slowly and wisely. Institutions and institutional rules should be strengthened, be accountable and made autonomous of cabals and individual who might want to manipulate the system for group or personal interests.

Keywords: Effective, Ethical, Finance, Management, Policy, Service Delivery 
Treasury Single Account - Transparency \& Accountability in Public Finance Mgt in Nigeria 343

\section{Introduction}

Treasury Single Account is a public accounting system under which all government revenue, receipts and income are collected into one single account, usually maintained by the country's Central Bank and all payments done through this account as well. The philosophical underpinning of TSA is primarily to ensure accountability of government revenue, enhance transparency and avoid misapplication and mismanagement of public funds. The proponents of Treasury Single Account argue that it will help to ensure proper cash management by eliminating idle funds usually left with different commercial banks and in a way enhance reconciliation of revenue collection and payment (Adeolu, 2015).

At a time when countries all over the world are contending with increased pressures on public financial balances, it is imperatives that public resources are used in the most effective, efficient and judicious way. Given that resources in the public sector are mostly generated through taxes and taxes create distortions in the allocation of resources and thus constrain economic growth, it is essential that public expenditures be used to improve long-term growth perspectives and take equity considerations into account. Improved efficiency and effectiveness of public spending not only helps maintain the fiscal discipline requested by them but also is instrumental in promoting the structural reform agenda of the present government. It alleviates budget constraints as it allows achieving the same results at lower levels of spending or increases value for money by achieving better outcomes at the same level of spending.

The payment of government revenue into multiple bank accounts operated by Ministries, Departments and Agencies (MDAs) in commercial banks, as obtained under the old order, was clearly against the Nigerian Constitution. Section 80(1) of the 1999 Constitution as amended states "All revenues, or other moneys raised or received by the Federation (not being revenues or other moneys payable under this Constitution or any Act of the National Assembly into any other public fund of the Federation established for a specific purpose) shall be paid into and form one Consolidated Revenue Fund of the Federation" (Yusuf \& Chiejina, 2015: 10). Successive governments have continued to operate multiple accounts for the collection and spending of government revenue in flagrant disregard to the provision of the Constitution, which requires that all government revenues be remitted into a single account. It was not until 2012 that government ran a pilot scheme for a single account using 217 MDAs as a test 
case. The pilot scheme saved Nigeria about N500 billion in frivolous spending. The success of the pilot scheme motivated the government to fully implement TSA, leading to the directives to banks to implement the technology platform that will help accommodate the TSA scheme (Okwe, Chijioke, Temiloluwa. \& David, 2015).

The Presidential directive in 2015 that all government revenues should be remitted to a Treasury Single Account is in consonance with this programme and in compliance with the provisions of the 1999 Constitution and also a determination to ensure discipline and greater transparency in the management of the nation's finances. According to the directive, all MDAs of government are expected to pay their earnings into a unified bank account known as Treasury Single Account (TSA). The directive applies to the MDAs that are funded from the Federation Account such as Nigerian National Petroleum Corporation (NNPC), the Central Bank of Nigeria (CBN), the Securities and Exchange Commission (SEC), and the Nigerian Ports Authority (NPA), Federal Universities, the Customs Service (NCS), Nigeria Immigration Service (NIS), Federal Inland Revenue Service (FIRS) and a host of others. The MDAs are to pay all their revenues to a sub-account linked to the TSA at CBN. To promote quick compliance with Presidential directive, the then Head of Service of the Federation (HSF), Danladi Kifasi, gave the name and number of the TSA as Accountant General (Federal sub-Treasury) Account No. 3000002095. The order on TSA, which came into effect on August 11 (2015), marks the beginning of MDAs' retirement of revenues due to the Federal Government into a unified account maintained by the Central Bank of Nigeria (CBN, 2015).

\section{Methodology}

The study adopts both qualitative and quantitative research design and descriptive analysis to gain an insight into the nature and character of TSA operations in Nigeria. The study draws its argument basically from secondary data, which include personal observation, newspapers, academic publication, and Internet sources. To improve on the reliability and validity of the study, multiple secondary sources were used to minimize errors.

The main argument germen to the article is that, TSA has become fait accompli in Nigeria. But rather than dissipate time and energy in questioning its desirability for public sector public financial management in Nigeria in particular and Africa in general, we ought to spend more time in examining its effect on the effective and efficient public 
sector management and the economy at large. It is against this backdrop that the article seeks to examine the paradoxical position of TSA in the public sector management and its correlate with the development crisis in Nigeria today. Thus, the future of TSA in public finance management in Nigeria will correctly be shaped by three important questions: What was the situation? What is the journey so? What are the challenges, prospects and the way forward? Indeed, Amilcar Cabral of Guinea Bissau once opined, "ideas and perspectives are moved forward through debates and not through a chorus". Let the debate on the evaluation and critique of TSA rage on.

\section{Conceptual and Theoretical Issues}

In order to avoid ambiguity in the interpretation and understanding of certain concepts, it is customary to begin an academic investigation by examining the conceptual and theoretical contours of the subject matter of analysis. This is the intent of Babbie \& Mouton (2001) methodological research diction that "we specify why we use particular terms for the purpose of facilitating their contextual definition and comprehension."

Treasury Single Account (TSA) is a public accounting system under which all government revenue, receipts and income are collected into one single account, usually maintained by the country's Central Bank and all payments done through this account as well. The purpose is primarily to ensure accountability of government revenue, enhance transparency and avoid misapplication of public funds. The maintenance of a Treasury Single Account will help to ensure proper cash management by eliminating idle funds usually left with different commercial banks and in a way enhance reconciliation of revenue collection and payment. To Eze (2015), treasure single account is a process and tool for effective management of government's finances, banking and cash position. In accordance with the name, it pools and unifies all government accounts through a single treasury account. Eze argued that, the consolidation into a TSA paves way for the timely capture and payment of all due revenues into government coffers without the intermediation of multiple banking arrangements. This prevents revenue leakages in terms of revenue loss and mismanagement by operators of all revenue-generating agencies. Chukwu (2015) described treasure single account (TSA) as a network of subsidiary accounts all linked to a main account such that transactions are effected in the subsidiary accounts but closing balances on these subsidiary accounts are transferred to the main account at the end of each business day. With the implementation of the 
Treasury Single Account, Ministries, Agencies and Departments (MDAs) will maintain their individual accounts with the commercial banks, but daily funding of their disbursements are made from the central or main account, which is resident with the Central Bank, just as their closing balances at the end of day are transferred to the main account. According to Chukwu, Prior to the implementation of the TSA, government was incurring finance cost on debit balances in some MDA's accounts while it was earning close to nothing on the credit balances of other MDAs. With the TSA, the net balances on all the MDA accounts will now reside with the Central Bank; hence, the government will avoid incurring interest costs when it has positive net position.

In a similar vein, Yusuf \& Chiejina (2015) see treasury Single Account as a unified structure of government bank account enabling consolidation and optimal utilisation of government cash resources. It is a bank account or a set of linked bank accounts through which the government transacts all its receipts and payments and gets a consolidated view of its cash position at any given time. A TSA therefore is considered a prerequisite for modern cash management and is an effective tool for the ministry of finance/treasury to establish oversight and centralized control over government's cash resources. For Khan \& Pessoa (2010), Treasure Single Account can be defined as a unified structure of government bank accounts enabling consolidation and optimum utilization of government cash resources. It separates transaction- level control from overall cash management. In other words, a TSA is a bank account or a set of linked bank accounts through which the government transacts all its receipts and payments and gets a consolidated view of its cash position at the end of each day. This banking arrangement for government transactions is based on the principle of fungibility of all cash irrespective of its end use. In a nutshell, a Treasury Single Account is a public accounting system under which all government revenue, receipts and income and collected into one single account, usually maintained by the country's Central Bank and all payments done through this account as well. The purpose is primarily to ensure accountability of government revenue, enhance transparency and avoid misapplication of public funds.

According to Pattanayak \& Cooper (2011), an effective TSA system is founded on three key principles: 
- The government banking arrangement should be unified, to enable ministry of finance oversight of government cash flows in and out of these bank accounts and allow complete fungibility of all cash resources, including on a real-time basis if electronic banking is in place. Although a TSA structure can contain ledger sub-accounts in a single banking institution (not necessarily a central bank), and can accommodate external zero-balance accounts (ZBAs) in a number of commercial banks, these separate accounts should be integrated with a top account (called the TSA main account) usually at the central bank for netting off their balances (usually at the end of each day) to get the consolidated cash position.

- No other government agency should operate bank accounts outside the oversight of the treasury. Institutional structures and transaction processing arrangements determine how a TSA is accessed and operated. The minister of finance, as the chief financial agent of the government, should manage the government's cash (and debt) positions to ensure that sufficient funds are available to meet financial obligations, idle cash is efficiently invested, and debt is optimally issued according to the appropriate statutes.

- The TSA should have comprehensive coverage, i.e., it should ideally include cash balances of all government entities, both budgetary and extra budgetary, to ensure full consolidation of government's cash resources.

There are several approaches through which an issue could be examined, especially in the social and management sciences where perspectives often differ based on a scholar's orientation and worldview. When issue of public sector reform is mentioned in contemporary times, the New Public Management (NPM) approach comes to mind. The New Public management approach which is one of several centres on the transition from traditional public administration theories to an arrangement that is workable, practicable and result oriented. Its emphasis is on good governance, technological innovation and democratization. New Public management approach is a relentless effort in the direction of greater transparency and accountability in resource allocation and performance management through the quality of service (Pollitt \& Bouckaert, 2004:65). 
New Public Management approach therefore, captures the basis of institutional and organization restructuring as an attempt to raise its performance and service by improving the quality of service delivery. According to Hood in (Pollitt \& Bouckaert, 2004:66), it is result focused rather than the process of result. Public management theory came up with different concepts for performance and service delivery principles to achieve it. Consequently, Hood identified the principles as accountability and transparency, efficiency and effectiveness; reduction of public sector (cost) expenditure; improvement in resource use through labour discipline; flexibility in decision making; competition in the public sector through decentralization and emphasis on result and not procedure in (Pollitt \& Bouckaert, 2004:66)

\section{The Origin of Treasury Single Account (TSA) in Nigeria}

Treasure Single Account is not a new concept; it has been adopted for decades in developed countries such as the United States, UK, France and developing economies of India and Indonesia. In Nigeria, the policy was first recommended by the Federal Government's Economic Reform and Governance Programme in 2004, but however dumped in 2005, following intense pressure from the banking industry. TSA is part of the Public Financial Management reforms which falls under the National Strategy for Public Service Reforms towards Vision 20:2020. The public financial management reforms were designed to address impediments to effective and efficient cash management.

It is globally recommended that no other government agency should operate bank accounts outside the oversight of the treasury. Institutional structures and transaction processing arrangements determine how a TSA is accessed and operated. The treasury, as the chief financial agent of the government, should manage the government's cash (and debt) positions to ensure that sufficient funds are available to meet financial obligations, idle cash is efficiently invested, and debt is optimally issued according to the appropriate statutes. In some cases, debt management including issuance of debt is done by a Debt Management Office (DMO). Judging by the provisions of the Financial Regulations (FR) and the 1999 Constitution of the Federal Republic of Nigeria, some Ministries/Extra-ministerial Offices, Agencies and other arms of government collect revenue (such as Value Added Tax (VAT), Withholding Tax (WHT), fees, fines and interest) are expected to remit same into the Consolidated Revenue Fund (CRF). 
Treasury Single Account - Transparency \& Accountability in Public Finance Mgt in Nigeria 349

\section{Benefits of Treasury Single Account}

The primary objective of a TSA is to ensure effective aggregate control over government cash balances. The consolidation of cash resources through a TSA arrangement is meant to optimize government cash management. It avoids borrowing and paying additional interest charges to finance the expenditures of some agencies while other agencies keep idle balances in their bank accounts. Effective aggregate control of cash is also a key element in monetary and budget management. Other objectives of a TSA include: reliable and efficient budget execution by minimizing transaction costs; monitoring (and thereby controlling the delay in) the remittance of government revenues (both tax and nontax) by the collecting banks; effective reconciliation between banking and accounting data; efficient control and monitoring of funds allocated to various government agencies; and facilitating better coordination with the monetary policy implementation (Garbade, John, \& Paul, 2004)

IMF in a 2010 paper titled Treasury Single Account: Concept, Design and Implementation Issues outlined the benefits of operating a Treasury Single Account. It started by explaining that the primary objective of a Treasury Single Account is to ensure effective aggregate control over government cash balances. Here are some of the benefits of Treasury Single Account;

Allows Complete and Timely Information on Government Cash Resources: In countries with advanced payment and settlement systems and an Integrated Financial Management Information System (IFMIS) with adequate interfaces with the banking system, this information will be available in real time. As a minimum, complete updated balances should be available daily.

Improves Appropriation Control: TSA ensures that the Management of public finance has full control over budget allocations, and strengthens the authority of the budget appropriation. When separate bank accounts are maintained, the result is often a fragmented system, where funds provided for budgetary appropriations are augmented by additional cash resources that become available through various creative, often extra-budgetary, measures.

Improves Operational Control during Budget Execution: When the treasury has full information about cash resources, it can plan and implement budget execution in an efficient, transparent, and reliable manner. The existence of 
uncertainty regarding whether the treasury will have sufficient funds to finance programmed expenditures may lead to sub-optimal behavior by budget entities, such as exaggerating their estimates for cash needs or channelling expenditures through off-budget arrangements.

Enables Efficient Cash Management: TSA facilitates regular monitoring of government cash balances. It also enables higher quality cash outturn analysis to be undertaken (e.g., identifying causal factors of variances and distinguishing causal factors from random variations in cash balances).

Reduces Bank fees and Transaction Costs: Reducing the number of bank accounts results in lower administrative cost for the government for maintaining these accounts, including the cost associated with bank reconciliation, and reduced banking fees.

Facilitates Efficient Payment Mechanisms: TSA ensures that there is no ambiguity regarding the volume or the location of the government funds which makes it possible to monitor payment mechanisms effectively. It can result in substantially lower transaction costs because of economies of scale in processing payments. The establishment of a Treasury Single Account is usually combined with elimination of the "float" in the banking and the payment systems, and the introduction of transparent fee and penalty structures for payment services. Many governments have achieved substantial reductions in their real cost of banking services by introducing a Treasury Single Account.

Improves Bank Reconciliation and Quality of Fiscal Data: A Treasury Single Account allows for effective reconciliation between the government accounting systems and cash flow statements from the banking system. This reduces the risk of errors in reconciliation processes, and improves the timeliness and quality of the fiscal accounts.

Lowers Liquidity Reserve Needs: TSA reduces the volatility of cash flows through the treasury, thus allowing it to maintain a lower cash reserve/buffer to meet unexpected fiscal volatility (IMF, 2010). 
In October 2013, former minister of finance, Ngozi Okonjo-Iweala, explained that the introduction of TSA had helped to reduce how government account was being overdrawn. She said, "93 MDAs had hooked on to the TSA platform while government's overdrawn position has dropped from N102 billion in 2011 to N19 billion in 2012" (Vanguard Editorial, 2015:18). The minister stressed that the implementation of the TSA play a central and strategic role in reforming the public financial management currently plagued with problems of corruption, high cost of governance. She said this will tackle the challenges of leakages in government revenue and wastages in expenditure patterns in MDAs (Vanguard Editorial, 2015:18).

It is also argued by Akanbi (2015) that the implementation of this programme is a critical step towards curbing corruption in public finance. In Akanbi view, this is in line with the commitment of the current administration to combat corrupt practices, eliminate indiscipline in public finance and ensure adequate fund flow that will be channelled to critical sectors of the economy to catalyse development. According to Usman in (Okwe et al, 2015:58),

Nigerians are excited at the directive by the President Buhari as this will mean that some government agencies that have been known to be withholding funds from the Federal Government are now under compulsion to remit monies to federal treasuries, The Treasury Single Account, had raising the prospect of transparency in government finances, it will assist the current administration to effectively manage the lean resources at its disposal.

For Otunla in (Okwe et al., 2015:58), fragmented banking affected the government's ability to undertake efficient cash planning and management as required by the Fiscal Responsibility Act. He said the government was also unable to track its expenditure in a timely manner and that the N70 billion lost in failed banks could be blamed on this. He maintained that the TSA resolution would also allow flexibility, "currently everyone is a slave to the system, and people need to be at their desk to effect transaction' (Okwe et al., 2015:58).

Otunla in (Okwe et al., 2015:58) explained further that TSA was online and in real time, meaning that it could be done from anywhere in the world. Once fully operational, 
transactions can be completed within 30 minutes, even if the individuals responsible are scattered across the globe. According to Obinna (2015:52):

The cardinal objective of TSA is to facilitate implementation of the Federal Government's Cash Management Policy, and to achieve greater accountability for public expenditure. This would ensure that sufficient cash was available as and when needed to meet commitments. He said it would control aggregate cash flow, improve the management of government domestic borrowing programme, enhance efficiency and enable investment of idle or excess cash.

Otunla in (Okwe et al., 2015:58) argue that so far the reform had instilled fiscal discipline and prudence as well as closed over 1,000 dormant or idle accounts; he however acknowledged that TSA was not without challenges. He argued that,

MDAs and commercial banks are resisting, some due to ignorance, others because previously they have been able to manipulate the system to their benefit which will not work under TSA. Some fear it will threaten the autonomy of certain agencies and give the accountant general power over them, this is not true. Other challenges include inadequate capacity in the form of access and ability to use the internet to do transactions.

This was also supported by an Abuja-based development economist, Enwegbara in (New Telegraph, 2015:17) who offered his views on the new policy. He said, for the first time in a long time, government money is going to be in government bank, the CBN. That is how good the news can be. No more can heads of revenue generating ministries, departments and agencies fix the revenues they generated in commercial banks' highinterest-yielding deposit accounts. And with that, illegally earn money (New Telegraph Editorial, 2015:17).

Enwegbara in (New Telegraph Editorial, 2015:17) argued that, in some cases, some non-revenue generating MDAs, do follow the footsteps of some revenue generating counterparts by placing their budgetary allocations in multiple high-interest-yielding deposit accounts, and with that divert money meant for financing both capital and recurrent 
Treasury Single Account - Transparency \& Accountability in Public Finance Mgt in Nigeria 353

\section{Treasury Single Account (TSA): The Journey So Far}

Theoretically, it is expected that TSA would bring about mutual benefit, halt economic injustice and engender financial discipline, transparency, accountability, a new economic and political order in Nigeria. However, in the public sector management and political economy of Nigeria, its impact has been a mixed bag of the good, the bad and the ugly.

Reactions to the government's directive have been mixed. Although there is a general belief that the regime of transparency which the new directive will engender, will assist the current administration to effectively manage the lean resources at its disposal. What this means is that henceforth, MDAs will no longer access public funds unless money from budgetary provisions. This is how it is supposed to be here in Nigeria as it is the case in modern economies around the world. This insistence on Treasury Single Account means fiscal discipline, efficiency, and accountability, on the part of government. In fact, this blockage of government's revenue diversion and looting using TSA besides leading to the consolidation of government revenues, incomes, and receipts, will lead to the optimal utilisation of government cash resources, including creative investment of public funds in the critical development sectors of the economy.

It also means that no longer at Bankers' Committee meetings member banks will demand that the CBN pursues their self-serving high interest rates to their benefits and those of heads of MDAs who placed public money in their high-interest-yielding fixed deposit accounts. With TSA, government can easily quarantine its revenues, with intended consequences including forcing interest rates to naturally nose-dive, since no serious business should be ready to borrow at such double digit rates when the economy is struggling at between four and five per cent (CBN, 2015).

One of the leading advocates of Treasury Single Account, Teriba, in (New Telegraph, 2015:18) said it is absolutely necessary for government to determine what comes to its cover at every given time. Speaking on a Channel Television programme, Teriba in (New Telegraph, 2015:18) noted that, "Prior to this time, many government agencies had the autonomy to receive money on behalf of the federal government or on behalf of the federation account and they had the liberty to spend part of the revenue because they were only required to remit only a fraction of the amount that they declared." He noted, however, that the privilege was increasingly being abused. He said, "We had agencies which handled capital projects and there were abuses. It is going to be beneficial to the country when all revenues accrued to the government come to one account. Let us 
know how money comes in. With this policy, all agencies will go through appropriation process without exception.

Dismissing the fear that the treasury single account system would encourage bureaucracy and delay in access to funds, Teriba (2015) explained that, there is no sacrifice that is too much to be taken to achieve transparency. According to him, "We should learn to take this country to a stage where we learn to be efficient. We cannot use the issue of efficiency to promote opacity. We need transparency. A situation where you don't know how much is due to government and government revenue gets intercepted will make it difficult for government to embark on developmental project (New Telegraph Editorial, 2015:21).

In her opinion, Managing Director, Head of Africa Macro and Global Research, Standard Chartered Bank, Razia Khan,

The directive on the TSA is an excellent step to ensure more transparency in government finances (it should be clearer what each agency is earning), and also to reduce the amount that government needs to borrow overall. Of course, this alone cannot compensate for weaker oil revenue, nor will it compensate for the arrears that will have to be paid, somehow. So while government borrowing will still rise, at least public finances will not be as pressured as they might have been in the absence of a TSA (Iroegbu, 2015: 18)

This was also supported by an Abuja-based development economist, Enwegbara, who offered his views on the new policy. He said, for the first time in a long time, government money is going to be in government bank, the CBN. That is how good the news can be. No more can heads of revenue generating ministries, departments and agencies fix the revenues they generated in commercial banks' high-interest-yielding deposit accounts. And with that, illegally earn money (New Telegraph Editorial, 2015:17).

He argued that, in some cases, some non-revenue generating MDAs, do follow the footsteps of some revenue generating counterparts by placing their budgetary allocations in multiple high-interest-yielding deposit accounts, and with that divert money meant for financing both capital and recurrent (New Telegraph Editorial, 2015:17).

The President, Ship Owners Association of Nigeria, Captain Labinjo explained that, spending by any government department in civilized countries are guided by their 
budgets, which make them to plan ahead, because they know what goes in and out of the treasury yearly. "But here the agencies spend their revenue the way they like, without question from any quarter, provided they give paltry sum to the Federal Government. Here, the agencies believe they are doing the government favour by giving a little fraction of their revenue, when it should be their statutory responsibility to the government to fund the government. So it is imperative for the government to know how much they are generating." He said all agencies, before now, demonstrated impunity in the way they spent public fund, because the country lacks institutions to check their excesses (Sun Editorial, 2015: 12).

Before the commencement of TSA, there was alleged fears that the implementation of TSA might disrupt operations of government agencies especially agencies like Nigerian Maritime Administration and Safety Agency (NIMASA), Nigerian Ports Authority (NPA) with huge daily operations. But stakeholders said it would rather promote accountability and responsible operations and make the government agencies to be more proactive and prudent because it would no longer be business as usual as their spending will now be backed by fiscal allocation (Sun Editorial, 2015: 12). However, available evidence suggests a contrary view as the operations almost all government agencies has come to hat as result of the adoption and implementation of TSA. This is in line with earlier position of Adefemi (2015) who argued that, the implementation of the policy has the capacity of crippling Ministries, Departments and Agencies (MDAs) as a result of bureaucracy in assessing needed fund for the smooth running of MDAs when the need arises.

TSA as lead to loss of job especial in the commercial banks that hitherto rely on government accounts for huge cash deposit. Today, the cash flow in these commercial banks has drastically reduced as a result of the Presidential directive on implementation of TSA in all federal government establishments.

\section{Concluding Remarks}

Many developing and low-income countries have fragmented government banking arrangements that hinder effective cash management and control over cash balances. It is common to find multiple bank accounts in commercial banks belonging to different ministries/agencies, with idle cash sitting there. It is believed and hope that if the policy is properly implemented, it will greatly improve the management of government 
revenue, it will pave way for the timely payment and capturing of all revenues going into the government treasury, without the intermediation of multiple banking arrangements that leads to financial corruption in the public sector. Besides, the system will likely reduce the mismanagement of public funds by revenue-generating agencies. It is also expected to help check the excess lack of accountability and lack of transparency in the way public fund is managed by MDAs. The consolidation of federal revenues in a single account will allow for easier and better tracking of funds, thereby enthroning a better regime of accountability and transparency in the public sector, in line with global best practice.

However, the fears that have been raised about the implications of the new measure are hardly necessary. There may be some legal barriers to full implementation of TSA. While Section162 of the Constitution regarding maintenance of Federation Account provides a broad legal framework it does not address the operational details. Some MDAs have financial autonomy granted to them by legislation including powers to maintain a fund from which to pay expenses and even to invest surplus funds and maintain a reserve.

Some MDAs generate revenue in various foreign currencies and TSA should also cater for them especially dealing with exchange difference accounting in their respective annual reports given that the means of establishing exchange differences at the end of the period by translating closing foreign currency balances may no longer be applicable. Another issue is the fears that it may delay government operations, as valuable time could be lost between payments and appropriations for spending. This is one reason why the co-operation of the National Assembly is necessary, to ensure timely appropriations and release of budgeted funds to government agencies. The MDAs, in collaboration with the Executive, will also need to be diligent in drawing up their budgets and presenting them for consideration and passage by the legislature. The financial regulators, including the $\mathrm{CBN}$, should also be proactive and institute measures to correct any lapses or negative impact of the policy, as no law or measure is foolproof. The fear that it will negatively affect commercial banks, and possibly lead to massive job losses, should be addressed. Total commitment and sincerity of purpose are required of those who are to implement this policy, what Nigeria requires at this time is the political will to push this reform measure through. 
There should be enhanced fiscal federalism as TSA transit accounts may be necessary for tax revenues that are centrally collected but are to be shared by the different levels of government such as VAT. It should in fact be possible to automatically allocate monies to states and local governments on a real time basis rather than on a monthly basis. States and local governments should also be encouraged to adopt TSA so that monthly federation account allocations can be paid directly into their TSAs held at the CBN thereby making it easier for the government to manage liquidity in the system thereby making fighting corruption at the state and local government level possible.

To cushion the liquidity impact on the financial system and the economy generally, an orderly migration of cash balances from the commercial bank accounts to the TSA should be considered, and complemented with monetary policy measures. Also the legal framework should be reviewed and amended where necessary while training should be provided to relevant staff of CBN and MDAs to ensure efficient implementation. Finally, the adoption of TSA in the country's public sector should progress slowly and wisely. Institutions and institutional rules should be strengthened, be accountable and made autonomous of cabals and individual who might want to manipulate the system for group or personal interests.

\section{List of References}

- Adefemi, O. 2015. Implementation of the treasury single account in Nigeria, ThisDay September 15 p 23

- Adeolu, I. A. 2015. Understanding the treasury single account (TSA) system -things you should know. Business \& Economy, Market Development. Abuja: Office of the Accountant General of the Federation

- Akanbi, D. 2015. Perspectives on treasury single (TSA) policy in Nigeria. Retrieved from http://dx.doi.org/10.2139/ssrn.2708051

- Central Bank of Nigeria 2014. Communiqué No. 94 of the monetary policy committee meeting, pp. 1-37 
- Central Bank of Nigeria 2015. Revised guidelines for compliance with treasury single account by banks in Nigeria, Abuja: CBN building

- Central Bank of Nigeria. 2015. Communiqué No. 94 of the monetary policy committee meeting, pp. 1-37

- Chukwu, J. 2015. The implementation of the TSA and the likely outcomes. Lagos: John Wiley \& Sons, Inc.

- Eze, O. 2016. The re-emergence of TSA in public resource management in Nigeria. ThisDay, January 15, p, 26

- Garbade, K., John C. P., \& Paul J. S. 2004. Recent innovations in treasury cash management, Current Issues in Economics and Finance, 10 (11), 21-32

- International Monetary Fund. 2010. Manual on fiscal transparency. Washington: International Monetary Fund.

- Iroegbu, C. (2015). Treasury single account will block leakages', Vanguard, August 24, p.38

- Khan, A., \& Pessoa, M. 2010. Conceptual design: d critical element of a government financial management information system project, technical notes and manuals. Washington: International Monetary Fund.

- Model, D. 2004. Public capital and economic growth: Issues of quantity, finance, and efficiency, Economic Development and Cultural Change, 48, (2):391

- New Telegraph Editorial 2016. Consolidated account will check impunity in MDAs, p,61

- Obinna, C. (2015). Banks face liquidity strain as FG fully enforces treasury single account, Thisday, August 11, p, 52.

- Okwe, A., Chijioke, N., Temiloluwa. A., \& David. O, 2015. Treasury Single Account: Giving Life to Jonathan's 'Dead' Policy Directives. Guardian, Pp 52-58

- Olson, O. J., Guthrie, J., \& Humprey, C. 1998. Global Warning: Debating International Developments in New Public Financial Management. Oslo: Cappelen.

- Pattanayak, S., \& Cooper, J. 2011. Chart of accounts: a critical element of the public financial management framework, technical notes and manuals Washington: International Monetary Fund

- Sun Editorial 2015. The new treasury single account. Retrived from http:/sunnewsonline.com/new/category/ editorial 
- Vanguard Editorial 2015. Treasury Single Account: Bank deposits loss may hit N2trn, Vanguard Editorial, August 17, p 18

- Yusuf, I.A., \& Chiejina, N. 2015. Anti-Graft War: One Economy, One Account. The Nation, August 16, pp 9-10 \&71

\section{AUTHORS' CONTACT:}

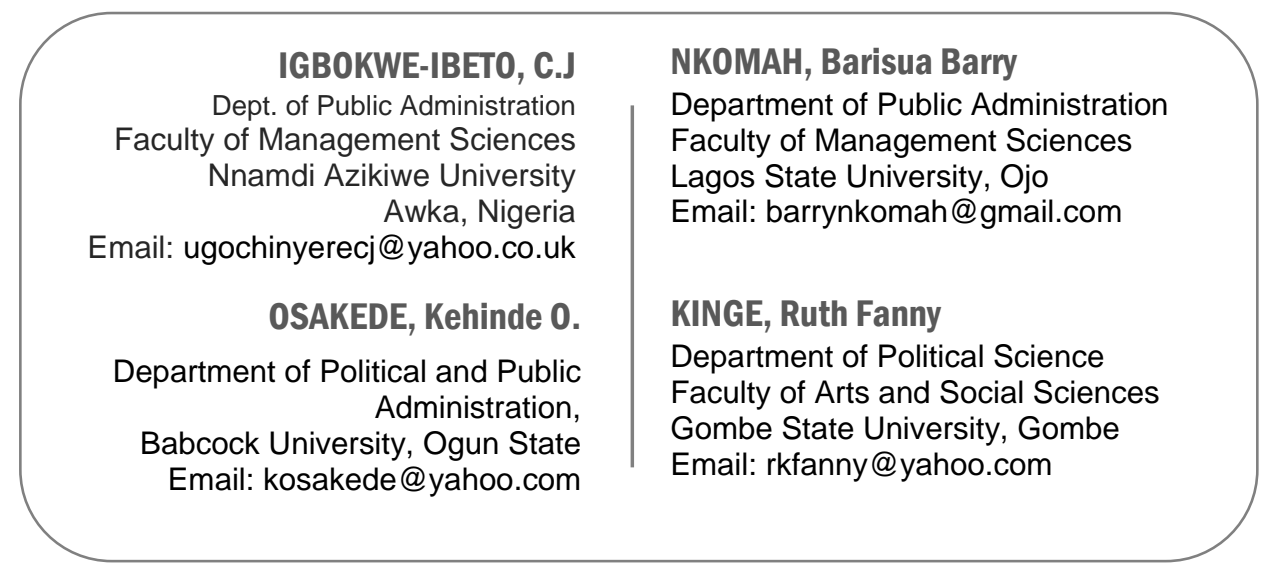

